\title{
Comparison of structural performance of open frame structures based on SNI 03-1726-2002 and SNI 03-1726-2012
}

\author{
Siti Aisyah Nurjannah ${ }^{1 *}$, Yoga Megantara², Erwin Lim $^{3}$, Iswandi Imran ${ }^{3}$ \\ ${ }^{1}$ Civil and Planning Engineering Department, Faculty of Engineering, Universitas Sriwijaya, Jl. Raya Palembang-Prabumulih \\ Km. 32, Indralaya, Indonesia \\ ${ }^{2}$ Center of Research and Development of People Residence, Ministry of Public Work and People Residence, Jl. Panyawungan, \\ Cileunyi, Bandung, Indonesia \\ ${ }^{3}$ Structure Research Group, Civil Engineering Department, Faculty of Civil and Environmental Engineering, \\ Institut Teknologi Bandung, Jalan Ganesha No. 10, Bandung 40132, Indonesia
}

\begin{abstract}
The performance analysis of a building structure under inelastic conditions consisted of static and dynamic methods, which each divided into linear and non-linear categories. The performance-based analysis was included in the non-linear static category and described in the Applied Technology Council (ATC)-40, Federal Emergency Management Agency (FEMA) 273, FEMA 356, and FEMA 440. In this study, some structural open frame models were assessed to determine the structural performance level. The aim of this study was to compare the performance of the open frame building structural models using pushover analysis based on SNI-1726-2002, SNI1726-2012, and ATC-40 codes. The structural element properties were modeled based on SNI-17262002 to represent the buildings previously constructed before the application of SNI-1726-2012. The results showed that the open frame structural models analysed based on SNI-1726-2012 code, had a lower performance points and structural performance levels compared to their counterpart models which were analysed based on SNI-1726-2002 code. Other models showed the opposite behavior due to differences in the characteristics of seismic zones, represented by the response spectrum curves in the SNI-1726-2002 and SNI-1726-2012 codes.
\end{abstract}

\section{Introduction}

The building structure analysis comprises of static and dynamic methods, with each consists of linear and nonlinear categories. The performance-based analysis is included in the non-linear static method and described in the Applied Technology Council (ATC)-40, Federal Emergency Management Agency (FEMA) 273, FEMA 274, FEMA 356 (the FEMA 273 language code), FEMA 440 (the enhancement of FEMA 356), National Earthquake Hazards Reduction Program (NEHRP) Guidelines for the Seismic Rehabilitation of Building, and Structural Engineers Association of California (SEAOC)'s Vision 2000: Performance-Based Seismic Engineering of Buildings (1995).

The performance level of a building structure is defined as a limitation associated with its degree of failure, which is determined by the physical damages of structural elements. In the pushover analysis, the building structure performance levels are categorized, as shown in Table 1 [1].

The aim of this study was to determine the performance points and structural performance levels of open frame structures designed using the previous Indonesian earthquake code [2] then compared the analysis and results by using the previous [2] and current [3] Indonesian earthquake codes.

Table 1. Buildings performance levels.

\begin{tabular}{|c|c|c|c|c|c|c|}
\hline \multirow[b]{2}{*}{$\begin{array}{l}\text { Non- } \\
\text { structural } \\
\text { perfor- } \\
\text { mance } \\
\text { levels }\end{array}$} & \multicolumn{6}{|c|}{ Structural performance levels } \\
\hline & $\begin{array}{l}\text { SP- } \\
1 \\
\text { IO }\end{array}$ & $\begin{array}{l}\text { SP-2 } \\
\text { DC } \\
\text { (ra- } \\
\text { nge) }\end{array}$ & $\begin{array}{l}\text { SP- } \\
3 \\
\text { LS }\end{array}$ & $\begin{array}{l}\text { SP-4 } \\
\text { li- } \\
\text { mit- } \\
\text { ed } \\
\text { safe- } \\
\text { ty } \\
\text { (ra- } \\
\text { nge) }\end{array}$ & $\begin{array}{l}\text { SP- } \\
5 \\
\text { SS }\end{array}$ & $\begin{array}{l}\text { SP- } \\
6 \\
\mathrm{NC}\end{array}$ \\
\hline NP-A O & $\begin{array}{l}1-\mathrm{A} \\
\mathrm{O}\end{array}$ & $2-\mathrm{A}$ & NR & NR & NR & NR \\
\hline NP-B IO & $\begin{array}{l}\text { 1-B } \\
\text { IO }\end{array}$ & $2-\mathrm{B}$ & $3-\mathrm{B}$ & NR & NR & NR \\
\hline NP-C LS & $1-\mathrm{C}$ & $2-\mathrm{C}$ & $\begin{array}{l}3-\mathrm{C} \\
\text { LS }\end{array}$ & $4-\mathrm{C}$ & $5-\mathrm{C}$ & $6-\mathrm{C}$ \\
\hline NP-D RH & NR & $2-\mathrm{D}$ & $3-\mathrm{D}$ & $4-\mathrm{D}$ & $5-\mathrm{D}$ & $6-\mathrm{D}$ \\
\hline NP-E NC & NR & NR & $3-\mathrm{E}$ & $4-\mathrm{E}$ & $\begin{array}{l}\text { 5-E } \\
\text { SS }\end{array}$ & NA \\
\hline
\end{tabular}

Notes:
O : Operational
A: unloaded condition
IO : Immediate Occupancy
DC : Damage Control

\footnotetext{
* Corresponding author: sitiaisyahn@ft.unsri.ac.id
} 


\author{
LS : Life Safety \\ RH : Reduced Hazards \\ SS : Structural Stability \\ $\mathrm{NC}:$ Not Considered \\ Legend \\ Commonly ref. building performance levels (SP-NP) \\ Other possible combination of SP-NP \\ Not recommended combinations of SP-NP
}

\section{Nonlinear static procedures}

In the performance-based theory, the pushover analysis is used to assess building structures in inelastic conditions through the formation of plastic hinges at the ends of beams and columns, to achieve specific structural performance levels under strong earthquakes. It generates a capacity curve, which correlates the base shear and roof displacement values (Fig. 1). Each point on the curve defines a specific damaged state. By correlating a capacity curve with a seismic demand curve that represents seismic characteristics of an earthquake zone, therefore the performance point on the capacity curve is obtained [1], from the responses of the structure under severe earthquakes [4].

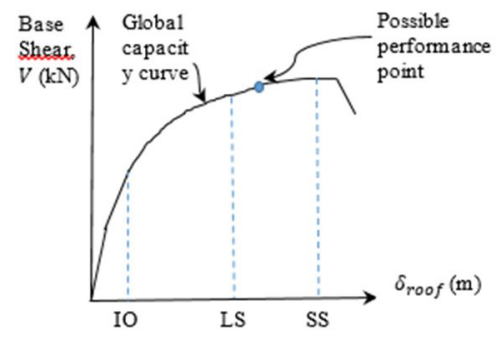

Fig. 1. Building structure capacity curve [1].

\subsection{Pushover analysis}

The pushover analysis is performed by applying increased lateral monotonic loads on the building structure that causes the structure achieves a specific boundary or failure. The structure reaction is based on the shear values that correlates with lateral load values. This reaction decreases after the structure achieves the maximum base shear due to failure.

The model of capacity curve shows structure condition since in unloaded condition (A), yield (B), nominal strength $(\mathrm{C})$, reduced strength (D), and ultimate (E) on Fig. 2.

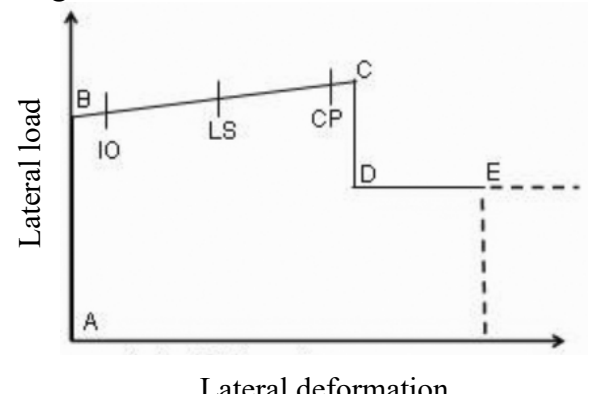

Fig. 2. Typical curve of lateral load-deformation [5]

\subsection{Converting the capacity curve}

The next step converts the capacity curve into a capacity spectrum (Fig. 3), which is known as AccelerationDisplacement Response Spectrum (ADRS) method. Equations 1 - 4 are used for the convertion [1]:

$$
\begin{gathered}
P F_{1}=\left[\frac{\sum_{i=1}^{N}\left(w_{i} \emptyset_{i 1}\right) / g}{\sum_{i=1}^{N}\left(w_{i} \varnothing_{i 1}^{2}\right) / g}\right] \\
\alpha_{1}=\frac{\left[\sum_{i=1}^{N}\left(w_{i} \varnothing_{i 1}\right) / g\right]}{\left[\sum_{i=1}^{N}\left(w_{i} / g\right)\right]\left[\left(w_{i} \varnothing_{i 1}^{2}\right) / g\right]} \\
S_{a}=\frac{V / W}{\alpha_{1}} \\
S_{d}=\frac{\Delta_{\text {roof }}}{P F_{1} \phi 1_{1, \text { roof }}}
\end{gathered}
$$

where:

$P F_{1} \quad$ is modal participation factor for the first natural mode

$\alpha_{1} \quad$ is modal mass coefficient for the first mode

$w_{i} / g$ is mass assigned to story-i

$\emptyset_{1, i} \quad$ is amplitude of mode- 1 at story- $\mathrm{i}$

$\emptyset_{1, \text { roof }}$ is amplitude of mode- 1 at the roof

$N \quad$ is number of building story

$V \quad$ is base shear

$W \quad$ is weight of the building (including self load and life load)

$\Delta_{\text {roof }}$ is roof displacement

$S_{a} \quad$ is spectral acceleration

$S_{d} \quad$ is spectral displacement

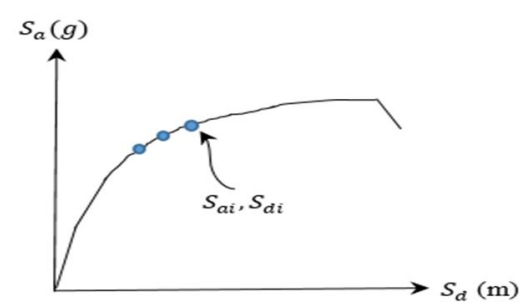

Fig. 3. Building structure capacity spectrum curves [1].

\subsection{Converting the response spectrum}

The common response spectrum is expressed in spectral acceleration $\left(S_{a}\right)$ and period $(T)$ curve (Fig. 4$)$. It needs to be converted into the ADRS format, also known as a demand spectrum (Fig. 5) using equations 5-7 [1].

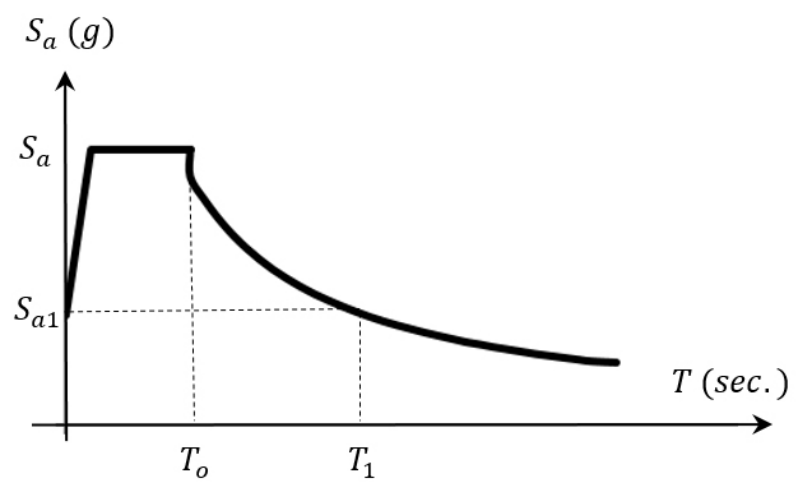

Fig. 4. Response spectrum [1] 


$$
\begin{aligned}
& S_{d i}=\frac{T_{i}^{2}}{4 \pi^{2}} S_{a i} g \\
& S_{a i} g=\frac{2 \pi}{T_{i}} S_{v} \\
& S_{d i}=\frac{T_{i}}{2 \pi} S_{v}
\end{aligned}
$$

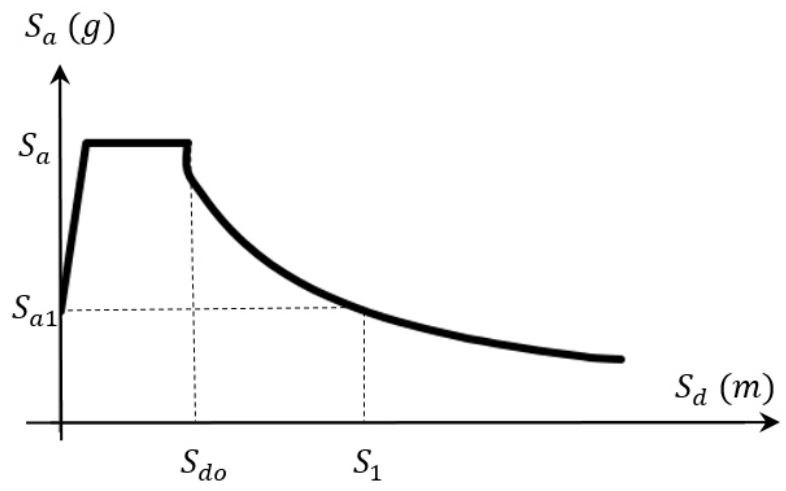

Fig. 5. Demand spectrum [1]

\subsection{Performance point and equivalent viscous damping}

The performance point is used to represent the performance level of a building structure under resisted earthquake loads. The performance point is located at the intersection of the demand spectrum and capacity curve. It correlates the maximum roof displacement (target displacement that occurs due to the earthquake) with the seismic acceleration.

The performance point location must satisfy the following two criteria: 1) it needs to be on the capacity spectrum curve to represent the structure condition on the certained displacement; and 2) it needs to be presented in the spectral demand curve reduced from the elastic, a 5\%damped design spectrum, to show a nonlinear demand at the same structural displacement [1]. In this method, the spectral reduction factors are defined to produce effective damping. This is calculated based on the capacity curve form, the estimated displacement demand, and the hysteretic curve. Some imperfections of a building's hysteretic curve, as effects of degradation and duration, are calculated in the reducted equivalent viscous damping values. The formula for viscous damping value is expressed in equation (8) as follows :

$$
\beta_{e q}=\beta_{o}+0.05
$$

where:

$\beta_{e q}$ is equivalent viscous damping of the structure

$\beta_{o}$ is hysteretic damping that represents equivalent viscous damping

0.005 is initial damping of the structure (inherent damping)

The analysis of performance point is conducted through iteration to satisfy the criteria above using three procedures for locating performance points, namely [1]:

1. Procedure A

This procedure is based on equations/formulas, and it is applied using spreadsheets.
2. Procedure B

In this procedure, the capacity curve is simplified into a bilinear curve which produces a relatively direct solution.

3. Procedure $\mathrm{C}$

This procedure is purely graphical and is similar to the capacity spectrum method.

According to these three methods, procedure A is the most transparent and direct, with its iteration conducted as follows:

1. Create a $5 \%$ damped (elastic) response spectrum that represents the seismic zone.

2. Convert the response spectrum into a demand spectrum (sub. 2.3).

3. Plot the response spectrum curve of earthquake loads and the capacity curve of the building structure into the same area.

4. Select the initial point for the iteration of performance point $\left(a_{p i}, d_{p i}\right)$ on the capacity curve.

5. Plot the bilinear lines on the capacity curve using equations (1-4).

6. Determine the spectral reduction factors using equations (9 and 10).

7. Check if the demand spectrum intersects the capacity spectrum at the point $\left(a_{p i}, d_{p i}\right)$ or the displacement where the demand spectrum intersects the capacity spectrum is in the allowed value of $d_{p i}$.

8. If the demand spectrum fails to intersect the capacity spectrum within a range of allowed value limits, then it needs to choose another point of $\left(a_{p i}, d_{p i}\right)$ and start over from step 4.

9. If the demand spectrum intersects the capacity spectrum within a range of allowed value limits, then the point of $\left(a_{p i}, d_{p i}\right)$ is the performance point $\left(a_{p}, d_{p}\right)$ and the displacement $\left(d_{p}\right)$ represents the maximum expected displacement of the structure due to the demand spectrum of earthquake.

$$
\begin{aligned}
S R_{A} & =\frac{1}{B_{S}} \approx \frac{3.21-0.68 \ln \left(\beta_{\text {eff }}\right)}{2.12} \\
& =\frac{3.21-0.68 \ln \left[\frac{63.7 \kappa\left(a_{y} d_{p i}-d_{y} a_{p i}\right)}{a_{p i} d_{p i}}+5\right]}{2.12}
\end{aligned}
$$

$\geq$ value in Table 2

$$
\begin{aligned}
S R_{V} & =\frac{1}{B_{L}} \approx \frac{2.31-0.41 \ln \left(\beta_{\text {eff }}\right)}{1.65} \\
& =\frac{2.31-0.41 \ln \left[\frac{63.7 \kappa\left(a_{y} d_{p i}-d_{y} a_{p i}\right)}{a_{p i} d_{p i}}+5\right]}{1.65} \\
& \geq \text { value in Table } 2 .
\end{aligned}
$$

The value of $S R_{A}, S R_{V}$, and the definition of structural behaviour types are described in Tables 2 and 3, respectively. 
Table 2. Minimum allowable $S R_{A}$ and $S R_{V}$ values [1].

\begin{tabular}{|l|r|r|}
\hline Structural behavior type & $S R_{A}$ & $S R_{V}$ \\
\hline A & 0.33 & 0.5 \\
\hline B & 0.44 & 0.56 \\
\hline C & 0.56 & 0.67 \\
\hline
\end{tabular}

Table 3. Structural behavior types [1].

\begin{tabular}{|l|l|l|l|}
\hline $\begin{array}{l}\text { Shaking } \\
\text { duration }\end{array}$ & $\begin{array}{l}\text { Essentially } \\
\text { new } \\
\text { building }\end{array}$ & $\begin{array}{l}\text { Average } \\
\text { existing } \\
\text { building }\end{array}$ & $\begin{array}{l}\text { Poor } \\
\text { existing } \\
\text { building }\end{array}$ \\
\hline Short & A & B & C \\
\hline Long & B & C & C \\
\hline
\end{tabular}

\section{Building structural models}

The 6-story open frame structural models were analysed. Each consisted of 3 bays on $\mathrm{X}$-axis and $\mathrm{Y}$-axis, with a span of 4 meters. One story height was 3 meters, with the structural models were designed as special moment resisting frames and operated as office buildings. The life and dead loads on the slabs were $300 \mathrm{~kg} / \mathrm{m}^{2}$ and $150 \mathrm{~kg} / \mathrm{m}^{2}$ respectively, while the dead load on the beams was 750 $\mathrm{kg} / \mathrm{m}$ which represented the masonry walls.

The following material properties were used: concrete compression strength $\left(f_{c}^{\prime}\right)$ of $28 \mathrm{MPa}$; mild steel yield and ultimate strength $\left(f_{y s}\right.$ and $\left.f_{u s}\right)$ of $240 \mathrm{MPa}$ and $370 \mathrm{MPa}$; steel bar yield and ultimate strength $\left(f_{y}\right.$ and $\left.f_{u}\right)$ of 400 $\mathrm{MPa}$ and $580 \mathrm{MPa}$, respectively.

All of the building structural models were designed based on the previous code [2] to represent that building structures were constructed before the application of the current code [3].

The beam and column properties are described in the Table 4. The dimension and reinforcement details of beams and columns were determined based on load combinations [6]. The column dimension and reinforcement details were the same for all structural models, while the required beam reinforcement details varied due to the load combinations, especially based on the specific earthquake loads on seismic zones. The thickness of all slabs was $120 \mathrm{~mm}$. Figure 6 shows the location of columns on the plans of the structural models.

Table 4. Beam and column properties

\begin{tabular}{|l|r|r|l|l|l|}
\hline Element & \multicolumn{1}{|c|}{$b$} & \multicolumn{1}{c|}{$h$} & \multicolumn{1}{c|}{$L$} & $A_{g}$ & $\rho$ \\
\hline & $(\mathrm{mm})$ & $(\mathrm{mm})$ & $(\mathrm{mm})$ & $\left(\mathrm{mm}^{2}\right)$ & $(\%)$ \\
\hline Beam & 250 & 400 & 4000 & $*$ & $*$ \\
\hline Column C1 & 300 & 300 & 3000 & $8 \mathrm{D} 19$ & 2.52 \\
\hline Column C2 & 400 & 400 & 3000 & $8 \mathrm{D} 25$ & 2.45 \\
\hline Column C3 & 325 & 325 & 3000 & $8 \mathrm{D} 19$ & 2.88 \\
\hline
\end{tabular}

Notes: * depends on the load combinations; $b$ : width; $h$ : height; $L$ : length; $A_{g}$ : reinforcement; $\rho$ : reinforcement percentage.

All capacity spectrum curves were compared to the demand spectrum curves of the previous [2] and current [3] Indonesian earthquake load codes to determine the performance points. The seismic properties of each structural model were based on the area where the cities were located along with the soil types as shown in Table
5. The period time $(T)$ were calculated using equation (11) [2].

where

$$
T=\zeta n
$$

$\zeta$ : the multiplier coefficient of the number of building structure floors that limits its fundamental natural period time; the values of coefficient depends on the seismic zone.

$n$ : number of story (was 6 in this study)

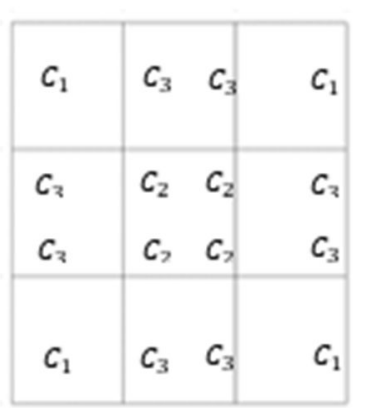

a. Floor 1

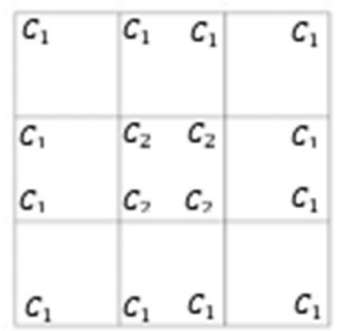

c. Floor 3

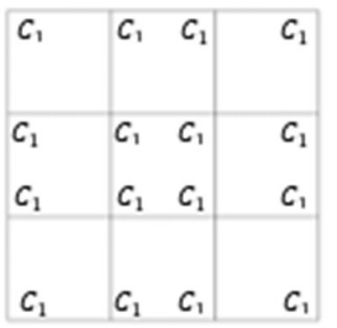

e. Floor 5

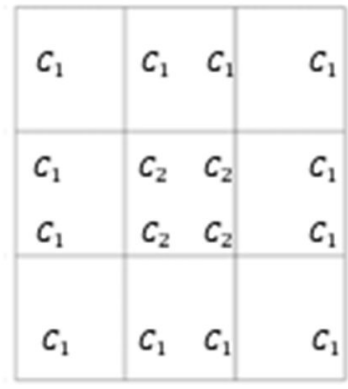

b. Floor 2

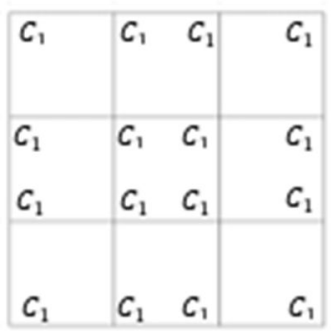

d. Floor 4

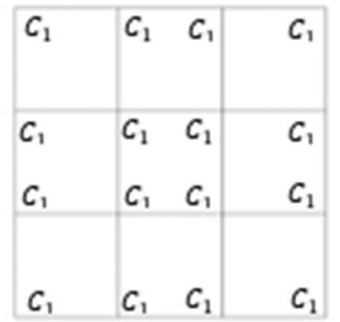

f. Floor 6
Fig. 6. Plans of the structural models

The value of earthquake reduction factor $(R)$ was 8.5 for reinforced concrete special moment resisting frames and the importance factor $(I)$ was 1 . In this study, seismic zones 1 and 2 were excluded due to their low seismic impact on building structures $[2,3]$. However, the spesific design, such as structure element dimensions and reinforcement details were unique and dependent on each designer [7]. The cities of Jakarta, Bandung, Padang, and Bengkulu were chosen to represent the seismic zones of $3,4,5$, and 6 [2].

The structural behavior type was B for reinforced concrete special moment resisting frames with values of coefficient of response modification $(R)$, system overstrength factor $\left(\Omega_{o}\right)$, and deflection amplification factor $\left(C_{d}\right)$ were 8,3 , and 5.5 , respectively [2] to determine the performance points. 
Table 5. Seismic properties

\begin{tabular}{|l|l|c|c|c|c|c|}
\hline Cities & $\begin{array}{l}\text { Soil } \\
\text { type }\end{array}$ & $\begin{array}{l}\text { Seismic } \\
\text { zone }\end{array}$ & $C_{a}$ & $C_{v}$ & & $T$ \\
\hline & & & $(\mathrm{g})$ & $(\mathrm{g})$ & & $(\mathrm{sec})$. \\
\hline Jakarta & Soft & 3 & 0.30 & 0.75 & 0.18 & 1.08 \\
& Medium & & 0.23 & 0.33 & & \\
& Hard & & 0.18 & 0.23 & & \\
\hline Bandung & Soft & 4 & 0.34 & 0.85 & 0.17 & 1.02 \\
& Medium & & 0.28 & 0.42 & & \\
& Hard & & 0.24 & 0.30 & & \\
\hline Padang & Soft & 5 & 0.36 & 0.90 & 0.16 & 0.96 \\
& Medium & & 0.32 & 0.50 & & \\
& Hard & & 0.28 & 0.35 & & \\
\hline Bengkulu & Soft & 6 & 0.38 & 0.95 & 0.15 & 0.90 \\
& Medium & & 0.36 & 0.54 & & \\
& Hard & & 0.33 & 0.42 & & \\
\hline
\end{tabular}

The plastic hinges were set on each beam and column ends. Furthermore, the hinge properties of all columns were arranged as a default of the program [5] and the hinge types were interacting P-M2-M3. The hinge types of all beams were moment M3. Each beam hinge properties were calculated based on the section dimension, longitudinal and transversal reinforcements [8], which consisted of values of moment/safety factor, rotation/safety factor, and yield moment. The values of rotation/safety factor (acceptance criteria) of IO, LS, and $\mathrm{CP}$ also were determined [1].

Each floor was set as a diaphragm to ensure it moved as a structural unity in lateral directions. Due to symmetrical behaviour of the structural models on $\mathrm{X}$ and $\mathrm{Y}$-axis, the pushover analysis was only determined on $\mathrm{X}$ axis.

\section{Results and analysis}

The structural models were deformed into inelastic condition due to earthquake loads by developing plastic hinges on the beam and column ends. The plastic hinges provide ductility and earthquake energy dissipation to ensure structure deformation and minimize severe damage [9]. In every step of pushover analysis, some new structural performance levels of plastic hinges were formed. It continued until the structural models achieved the displacement target on the building roof [10].

The beam reinforcements of all models are shown in Tables 6 and 7. The differences of the reinforcement depended on the load combinations, mostly through specific earthquake loads in the seismic zones.

The results and analysis of all load combinations were the minimum required reinforcements of beams and columns. All columns showed capacity ratios were less than 1.0, which indicated that the dimension and reinforcement details satisfied the requirements [11].

All pushover curves of structural models are shown in Figures 7 to 10. Each curve was unique due to specific beam reinforcement and hinge properties of the structural models, which were referred to the earthquake loads on the seismic zones. The $\mathrm{X}$ and $\mathrm{Y}$-axis values provide information of roof lateral displacement $(d)$ and shear force $(V)$, respectively.
Table 6. Required beam reinforcement

\begin{tabular}{|c|c|c|c|c|c|}
\hline \multirow[t]{4}{*}{ No. } & \multirow[t]{4}{*}{ City } & \multirow{4}{*}{$\begin{array}{l}\text { Seismic } \\
\text { zone }\end{array}$} & \multirow{4}{*}{$\begin{array}{l}\text { Soil } \\
\text { type }\end{array}$} & \multirow{2}{*}{\multicolumn{2}{|c|}{$\begin{array}{l}\text { Beam } \\
A_{s} \text { required at } \\
\text { support }\end{array}$}} \\
\hline & & & & & \\
\hline & & & & Top & Bottom \\
\hline & & & & $\left(\mathrm{mm}^{2}\right)$ & $\left(\mathrm{mm}^{2}\right)$ \\
\hline 1 & Jakarta & 3 & Soft & 586 & 344 \\
\hline 2 & Jakarta & 3 & Medium & 333 & 218 \\
\hline 3 & Jakarta & 3 & Hard & 302 & 180 \\
\hline 4 & Bandung & 4 & Soft & 680 & 404 \\
\hline 5 & Bandung & 4 & Medium & 401 & 262 \\
\hline 6 & Bandung & 4 & Hard & 325 & 213 \\
\hline 7 & Padang & 5 & Soft & 725 & 477 \\
\hline 8 & Padang & 5 & Medium & 471 & 302 \\
\hline 9 & Padang & 5 & Hard & 370 & 242 \\
\hline 10 & Bengkulu & 6 & Soft & 760 & 510 \\
\hline 11 & Bengkulu & 6 & Medium & 523 & 302 \\
\hline 12 & Bengkulu & 6 & Hard & 436 & 284 \\
\hline
\end{tabular}

Table 7. Applied beam reinforcement

\begin{tabular}{|c|c|c|c|c|c|c|c|c|}
\hline \multirow[t]{4}{*}{ No. } & \multicolumn{8}{|c|}{ Beam } \\
\hline & \multicolumn{6}{|c|}{ As applied at support } & \multicolumn{2}{|c|}{ As applied at support } \\
\hline & \multicolumn{3}{|c|}{ Top } & \multicolumn{3}{|c|}{ Bottom } & \multirow{2}{*}{$\begin{array}{l}\text { Top } \\
\left(\mathrm{mm}^{2}\right)\end{array}$} & \multirow{2}{*}{\begin{tabular}{|l|} 
Bottom \\
$\left(\mathrm{mm}^{2}\right)$ \\
\end{tabular}} \\
\hline & & & & & & & & \\
\hline 1 & 3 & & & 3 & $\mathrm{D}$ & 13 & 603.19 & 398.20 \\
\hline 2 & 3 & $\mathrm{D}$ & 13 & 2 & $\mathrm{D}$ & 13 & 398.20 & 265.46 \\
\hline 3 & 3 & D & 13 & 2 & D & 13 & 398.20 & 265.46 \\
\hline 4 & 2 & $\mathrm{D}$ & 22 & 2 & $\mathrm{D}$ & 19 & 76 & 567.06 \\
\hline 5 & 2 & D & 16 & 2 & $\mathrm{D}$ & 13 & 402.12 & 265.46 \\
\hline 6 & 3 & $\mathrm{D}$ & 13 & 2 & $\mathrm{D}$ & 13 & 398.20 & 265.46 \\
\hline 7 & 2 & D & 22 & 2 & $\mathrm{D}$ & 19 & 760.27 & 567.06 \\
\hline 8 & 2 & D & 19 & 3 & D & 13 & 567.06 & 398.20 \\
\hline 9 & 3 & D & 13 & 2 & D & 13 & 398.20 & 265.46 \\
\hline 10 & 2 & $\mathrm{D}$ & 22 & 2 & $\mathrm{D}$ & 19 & 760.27 & 567.06 \\
\hline 11 & 2 & $\mathrm{D}$ & 19 & 2 & $\mathrm{D}$ & 16 & 567.06 & 402.12 \\
\hline 12 & 2 & $\mathrm{D}$ & 19 & 3 & $\mathrm{D}$ & 13 & 567.06 & 398.20 \\
\hline
\end{tabular}

The roof target displacement i.e. $200 \mathrm{~mm}$ were achieved by all structural models, while the maximum lateral force was different as shown in Table 8.

All structural models used seismic design category B which represented a moderate reduction of hysteretic loop areas of structural responses with $\kappa$ of $2 / 3$. The $\kappa$-factor is a measure of the extent to which the actual building hysteretic behaviour [1]. The response spectrum curves of all cities and soil types were provided through an official Indonesian seismic map [12].

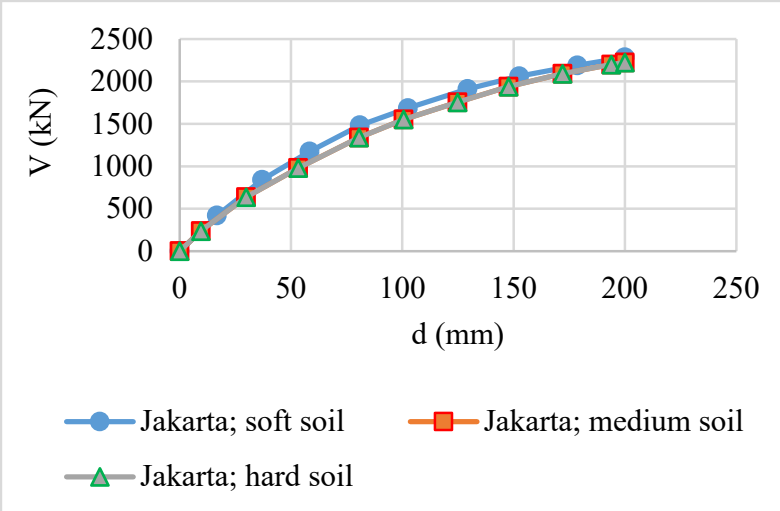

Fig. 7. Pushover curves of structural models in Jakarta city 


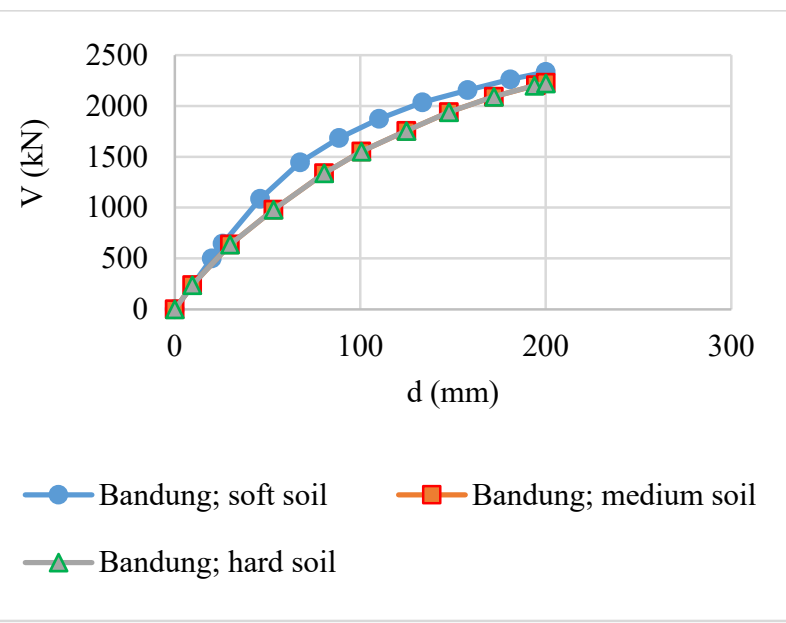

Fig. 8. Pushover curves of structural models in Bandung city

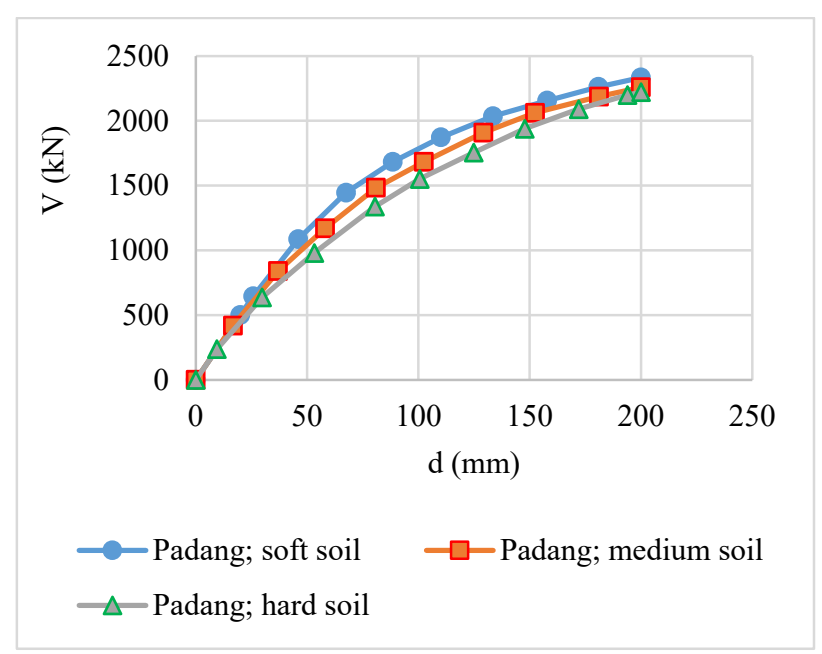

Fig. 9. Pushover curves of structural models in Padang city

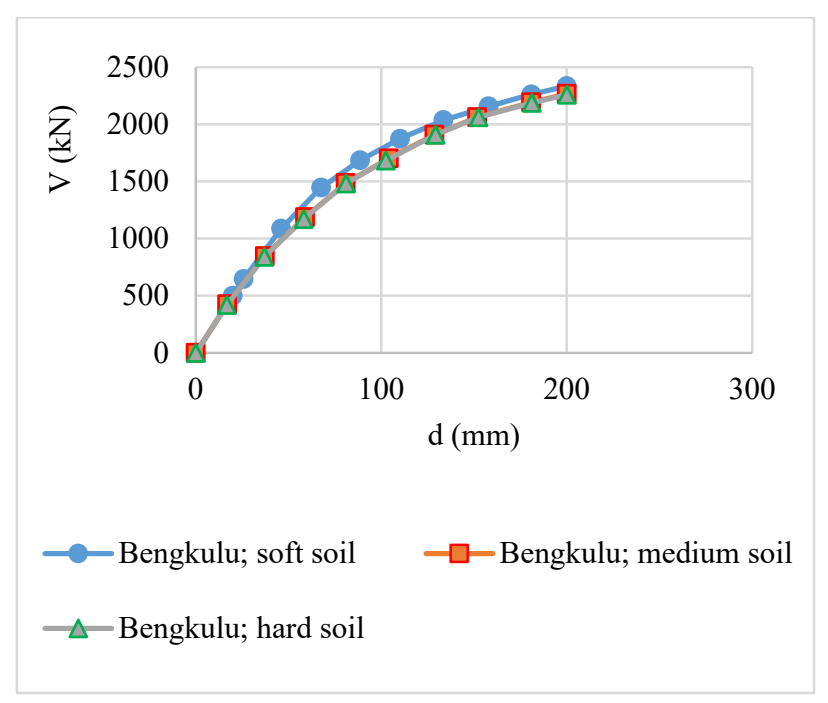

Fig. 10. Pushover curves of structural models in Bengkulu city
Table 8. Maximum displacement $\left(d_{\max }\right)$ and lateral force $\left(V_{\max }\right)$

\begin{tabular}{|l|l|l|l|}
\hline City & Soil type & $\mathrm{d}_{\max }$ & $\mathrm{V}_{\max }$ \\
\cline { 3 - 4 } & & $(\mathrm{mm})$ & $(\mathrm{kN})$ \\
\hline Jakarta & Soft & 200.001 & 2283.767 \\
& Medium & 200.001 & 2222.701 \\
& Hard & 200.001 & 2222.701 \\
\hline Bandung & Soft & 200.001 & 2334.539 \\
& Medium & 200.001 & 2228.283 \\
& Hard & 200.001 & 2222.701 \\
\hline Padang & Soft & 200.001 & 2334.539 \\
& Medium & 200.001 & 2258.895 \\
& Hard & 200.001 & 2222.701 \\
\hline Bengkulu & Soft & 200.001 & 2334.539 \\
& Medium & 200.001 & 2266.678 \\
& Hard & 200.001 & 2258.895 \\
\hline
\end{tabular}

Figures 11 and 12 showed that the performance point properties $\left(S_{a}, S_{d}\right)$ are not the same due to different response spectrum curves of the previous [2] and current [3] Indonesian earthquake load codes. The current [3] maximum spectral response acceleration parameters $\left(C_{v}\right.$ or $S_{a}$ ) of Jakarta city on soft soil was less than the previous one [2]. Therefore, it influenced the structural model performance in resisting earthquake. The same behaviour occurred on other models of Jakarta on medium and hard soil; Bandung on soft soil; Padang on soft and medium soil; also Bengkulu on hard, medium, and soft soil. The opposite behaviour showed by the structural models under earthquake of Bandung on medium and hard soil; and Padang on hard soil (Fig. 13 and 14). In simplifying this study, only four figures of the spectral acceleration-spectral displacement curves are shown. The performance points and structural performance levels of all 12 open frame structural models were determined, each by using response spectrum curves of the previous [2] and current [3] Indonesian earthquake load codes as shown in Tables 9 to 11 .

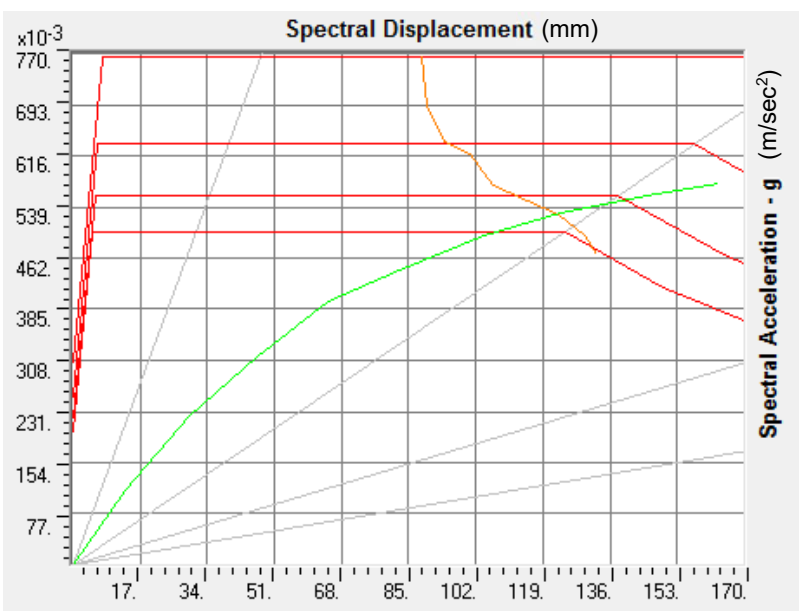

Fig. 11. Pushover curves of a structural model and response spectrum curves of Jakarta city based on the previous earthquake code [2] of soft soil 


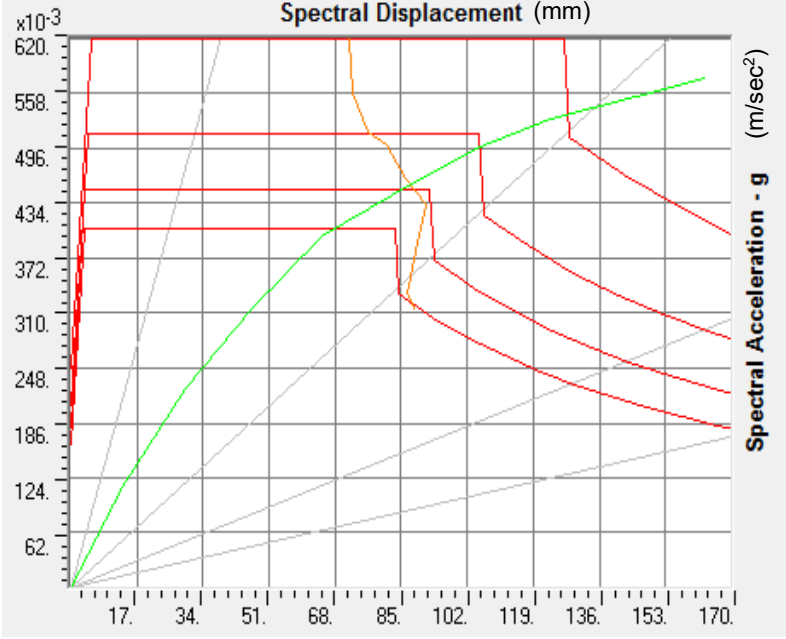

Fig. 12. Pushover curves of a structural model and response spectrum curves of Jakarta city based on the recent earthquake code [3] of soft soil

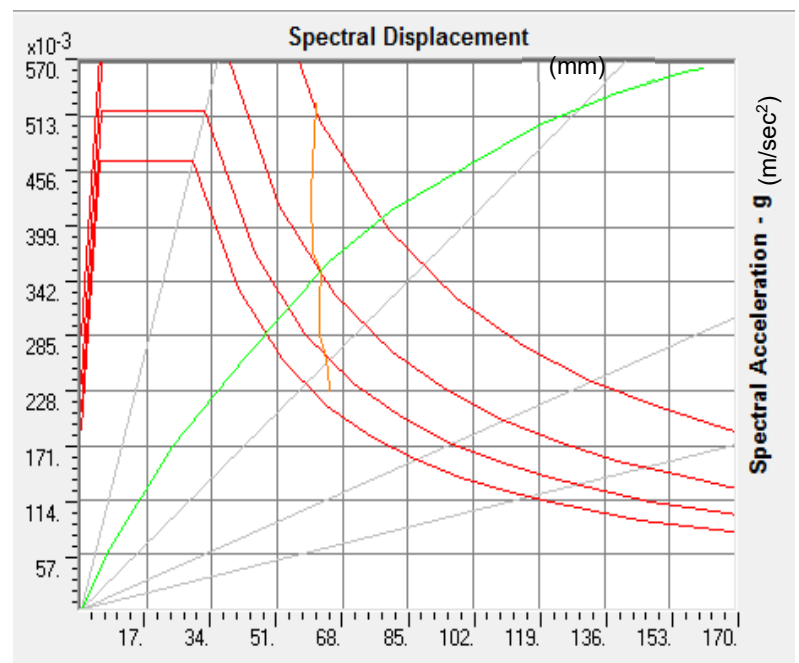

Fig. 13. Pushover curves of a structural model and response spectrum curves of Padang city based on the previous earthquake code [2] of hard soil

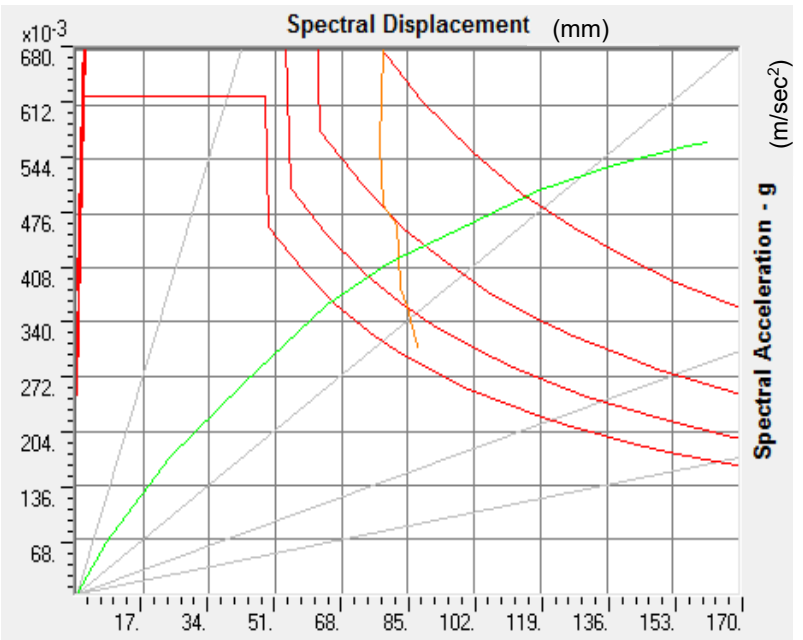

Fig. 14. Pushover curves of a structural model and response spectrum curves of Padang city based on the recent earthquake code [3] of hard soil
Table 9. Performance points $(V-d)$

\begin{tabular}{|r|l|l|l|r|r|}
\hline No. & City & \multirow{2}{*}{$\begin{array}{l}\text { Soil } \\
\text { type }\end{array}$} & $\begin{array}{l}\text { Code } \\
\text { vers- } \\
\text { ion }\end{array}$ & & \multicolumn{2}{l|}{$\begin{array}{l}\text { Performance points } \\
(d)\end{array}$} & $\begin{array}{l}\text { Deformation } \\
(V)\end{array}$ \\
\cline { 5 - 6 } & & & & $(\mathrm{mm})$ & $(\mathrm{kN})$ \\
\hline 1 & Jakarta & $\mathrm{S}$ & 2002 & 151.966 & 2058.573 \\
& & & 2012 & 108.334 & 1733.843 \\
\hline 2 & Jakarta & $\mathrm{M}$ & 2002 & 72.577 & 1233.548 \\
& & & 2012 & 68.727 & 1183.022 \\
\hline 3 & Jakarta & $\mathrm{H}$ & 2002 & 49.639 & 926.965 \\
& & & 2012 & 55.805 & 1013.455 \\
\hline 4 & Bandung & $\mathrm{S}$ & 2002 & 167.336 & 2199.403 \\
& & & 2012 & 145.743 & 2095.862 \\
\hline 5 & Bandung & $\mathrm{M}$ & 2002 & 93.806 & 1479.055 \\
& & & 2012 & 97.772 & 1521.233 \\
\hline 6 & Bandung & $\mathrm{H}$ & 2002 & 65.739 & 1143.815 \\
& & & 2012 & 84.420 & 1379.287 \\
\hline 7 & Padang & $\mathrm{S}$ & 2002 & 182.572 & 2268.175 \\
& & & 2012 & 165.782 & 2192.255 \\
\hline 8 & Padang & $\mathrm{M}$ & 2002 & 103.071 & 1687.402 \\
& & & 2012 & 110.503 & 1750.212 \\
\hline 9 & Padang & $\mathrm{H}$ & 2002 & 77.956 & 1304.140 \\
& & & 2012 & 103.405 & 1574.946 \\
\hline 10 & Bengkulu & $\mathrm{S}$ & 2002 & 196.123 & 2319.773 \\
& & & 2012 & 114.366 & 1901.894 \\
\hline 11 & Bengkulu & $\mathrm{M}$ & 2002 & 111.704 & 1764.962 \\
& & & 2012 & 93.475 & 1602.170 \\
\hline 12 & Bengkulu & $\mathrm{H}$ & 2002 & 87.791 & 1545.995 \\
& & & 2012 & 81.481 & 1487.391 \\
\hline
\end{tabular}

Notes: $\mathrm{S}=$ soft; $\mathrm{M}=$ medium; $\mathrm{H}=$ hard

Table 10. Performance points $\left(S_{a}-S_{d}\right)$

\begin{tabular}{|r|l|r|l|l|l|r|}
\hline No. & City & $\begin{array}{l}\text { Seis- } \\
\text { mic }\end{array}$ & $\begin{array}{l}\text { Soil } \\
\text { type }\end{array}$ & $\begin{array}{l}\text { Code } \\
\text { vers- } \\
\text { ion }\end{array}$ & & \multicolumn{2}{l}{$\begin{array}{l}\text { Performance } \\
\text { points }\end{array}$} \\
\cline { 5 - 7 } & & zone & & & $\begin{array}{l}S_{a} \\
\text { (g) }\end{array}$ & \multicolumn{1}{l}{$\begin{array}{l}S_{d} \\
(\mathrm{~mm})\end{array}$} \\
\hline 1 & Jakarta & 3 & $\mathrm{~S}$ & 2002 & 0.528 & 122.935 \\
& & & & 2012 & 0.455 & 87.079 \\
\hline 3 & Jakarta & 3 & $\mathrm{M}$ & 2002 & 0.333 & 57.973 \\
& & & & 2012 & 0.319 & 54.899 \\
\hline 4 & Bakarta & 3 & $\mathrm{H}$ & 2002 & 0.249 & 39.624 \\
& & & & 2012 & 0.272 & 44.580 \\
\hline 5 & Bandung & 4 & $\mathrm{~S}$ & 2002 & 0.553 & 136.847 \\
& & 4 & $\mathrm{M}$ & 2002 & 0.397 & 74.954 \\
\hline 6 & Bandung & 4 & $\mathrm{H}$ & 2002 & 0.308 & 52.513 \\
& & & & 2012 & 0.372 & 67.439 \\
\hline 7 & Padang & 5 & $\mathrm{~S}$ & 2002 & 0.568 & 149.765 \\
& & & & 2012 & 0.552 & 135.531 \\
\hline 8 & Padang & 5 & $\mathrm{M}$ & 2002 & 0.444 & 82.782 \\
& & & & 2012 & 0.458 & 88.857 \\
\hline 9 & Padang & 5 & $\mathrm{H}$ & 2002 & 0.352 & 62.269 \\
& & & & 2012 & 0.420 & 82.667 \\
\hline 10 & Bengkulu & 6 & $\mathrm{~S}$ & 2002 & 0.579 & 161.349 \\
& & & & 2012 & 0.491 & 92.198 \\
\hline 11 & Bengkulu & 6 & $\mathrm{M}$ & 2002 & 0.462 & 89.840 \\
& & & & 2012 & 0.425 & 74.966 \\
\hline 12 & Bengkulu & 6 & $\mathrm{H}$ & 2002 & 0.412 & 70.338 \\
& & & & 2012 & 0.399 & 65.200 \\
\hline
\end{tabular}


Table 11. Performance points $\left(T_{e f f}-\beta_{e f f}\right)$

\begin{tabular}{|c|c|c|c|c|c|c|}
\hline \multirow[t]{2}{*}{ No. } & \multirow[t]{2}{*}{ City } & \multirow{2}{*}{$\begin{array}{l}\text { Seis- } \\
\text { mic } \\
\text { zone }\end{array}$} & \multirow[t]{2}{*}{$\begin{array}{l}\text { Soil } \\
\text { type }\end{array}$} & \multirow{2}{*}{$\begin{array}{l}\text { Code } \\
\text { vers- } \\
\text { ion }\end{array}$} & \multicolumn{2}{|c|}{$\begin{array}{l}\text { Performance } \\
\text { points }\end{array}$} \\
\hline & & & & & $\begin{array}{l}T_{\text {eff }} \\
\text { (sec.) }\end{array}$ & $\beta_{\text {eff }}$ \\
\hline 1 & Jakarta & 3 & $\mathrm{~S}$ & $\begin{array}{l}2002 \\
2012\end{array}$ & $\begin{array}{l}0.968 \\
0.877\end{array}$ & $\begin{array}{l}0.174 \\
0.142\end{array}$ \\
\hline 2 & Jakarta & 3 & $\mathrm{M}$ & $\begin{array}{l}2002 \\
2012\end{array}$ & $\begin{array}{l}0.835 \\
0.829\end{array}$ & $\begin{array}{l}0.101 \\
0.101\end{array}$ \\
\hline 3 & Jakarta & 3 & $\mathrm{H}$ & $\begin{array}{l}2002 \\
2012\end{array}$ & $\begin{array}{l}0.797 \\
0.810\end{array}$ & $\begin{array}{l}0.096 \\
0.100\end{array}$ \\
\hline 4 & Bandung & 4 & $\mathrm{~S}$ & $\begin{array}{l}2002 \\
2012\end{array}$ & $\begin{array}{l}0.997 \\
0.946\end{array}$ & $\begin{array}{l}0.209 \\
0.191\end{array}$ \\
\hline 5 & Bandung & 4 & $\mathrm{M}$ & $\begin{array}{l}2002 \\
2012\end{array}$ & $\begin{array}{l}0.871 \\
0.878\end{array}$ & $\begin{array}{l}0.112 \\
0.115\end{array}$ \\
\hline 6 & Bandung & 4 & $\mathrm{H}$ & $\begin{array}{l}2002 \\
2012\end{array}$ & $\begin{array}{l}0.825 \\
0.853\end{array}$ & $\begin{array}{l}0.101 \\
0.105\end{array}$ \\
\hline 7 & Padang & 5 & $\mathrm{~S}$ & $\begin{array}{l}2002 \\
2012\end{array}$ & $\begin{array}{l}1.030 \\
0.994\end{array}$ & $\begin{array}{l}0.217 \\
0.208\end{array}$ \\
\hline 8 & Padang & 5 & $\mathrm{M}$ & $\begin{array}{l}2002 \\
2012\end{array}$ & $\begin{array}{l}0.866 \\
0.882\end{array}$ & $\begin{array}{l}0.139 \\
0.144\end{array}$ \\
\hline 9 & Padang & 5 & $\mathrm{H}$ & $\begin{array}{l}2002 \\
2012\end{array}$ & $\begin{array}{l}0.843 \\
0.889\end{array}$ & $\begin{array}{l}0.102 \\
0.119\end{array}$ \\
\hline 10 & Bengkulu & 6 & $\mathrm{~S}$ & $\begin{array}{l}2002 \\
2012\end{array}$ & $\begin{array}{l}1.059 \\
0.869\end{array}$ & $\begin{array}{l}0.223 \\
0.160\end{array}$ \\
\hline 11 & Bengkulu & 6 & $\mathrm{M}$ & $\begin{array}{l}2002 \\
2012\end{array}$ & $\begin{array}{l}0.883 \\
0.841\end{array}$ & $\begin{array}{l}0.145 \\
0.125\end{array}$ \\
\hline 12 & Bengkulu & 6 & $\mathrm{H}$ & $\begin{array}{l}2002 \\
2012\end{array}$ & $\begin{array}{l}0.827 \\
0.811\end{array}$ & $\begin{array}{l}0.118 \\
0.109\end{array}$ \\
\hline
\end{tabular}

Table 12. Structural performance level on performance point

\begin{tabular}{|c|c|c|c|}
\hline \multirow{2}{*}{$\begin{array}{l}\text { No./ } \\
\text { city/ } \\
\text { soil } \\
\text { type }\end{array}$} & \multirow{2}{*}{$\begin{array}{l}\text { Code } \\
\text { vers- } \\
\text { ion }\end{array}$} & \multicolumn{2}{|c|}{ Performance points } \\
\hline & & $\begin{array}{l}\text { Maximum } \\
\text { Level }\end{array}$ & Structure elements \\
\hline \multirow{2}{*}{$\begin{array}{r}1 / \\
\mathrm{Jkt} / \\
\mathrm{S}\end{array}$} & 2002 & $\mathrm{IO}$ & Columns (floor 1-4) \\
\hline & 2012 & IO & Columns (floor 1) \\
\hline \multirow{2}{*}{$\begin{array}{r}2 / \\
\mathrm{Jkt} / \\
\mathrm{M}\end{array}$} & 2002 & B & $\begin{array}{l}\text { Beams (floor 2-6); columns } \\
\text { (floor 1; edge frames) }\end{array}$ \\
\hline & 2012 & $\mathrm{~B}$ & $\begin{array}{l}\text { Beams (floor 2-6); columns } \\
\text { (floor 1; edge frames) }\end{array}$ \\
\hline \multirow{2}{*}{$\begin{array}{r}3 / \\
\mathrm{Jkt} / \\
\mathrm{H} \\
\end{array}$} & 2002 & $\mathrm{~B}$ & Beams (floor 2-6) \\
\hline & 2012 & $\mathrm{~B}$ & $\begin{array}{l}\text { Beams (floor 2-6); columns } \\
\text { (floor 1; edge frames) }\end{array}$ \\
\hline \multirow{2}{*}{$\begin{array}{r}4 / \\
\text { Bdg/ } \\
\mathrm{S}\end{array}$} & 2002 & IO & $\begin{array}{l}\text { Columns (floor 1-2; edge } \& \\
\text { middle frames) }\end{array}$ \\
\hline & 2012 & $\mathrm{IO}$ & $\begin{array}{l}\text { Columns (floor 1; edge } \\
\text { frames) }\end{array}$ \\
\hline \multirow{2}{*}{$\begin{array}{r}5 / \\
\mathrm{Bdg} / \\
\mathrm{M}\end{array}$} & 2002 & B & $\begin{array}{l}\text { Beams (floor 2-6); columns } \\
\text { (floor 1-4; middle and edge } \\
\text { frames) }\end{array}$ \\
\hline & 2012 & $\mathrm{~B}$ & $\begin{array}{l}\text { Beams (floor 2-6); columns } \\
\text { (floor 1-4; middle and edge } \\
\text { frames) }\end{array}$ \\
\hline \multirow{2}{*}{$\begin{array}{r}6 / \\
\mathrm{Bdg} / \\
\mathrm{H}\end{array}$} & 2002 & $\mathrm{~B}$ & $\begin{array}{l}\text { Beams (floor 2-6); columns } \\
\text { (floor 1; edge and middle } \\
\text { frames) }\end{array}$ \\
\hline & 2012 & $\mathrm{~B}$ & $\begin{array}{l}\text { Beams (floor 2-6); columns } \\
\text { (floor 1; edge and middle } \\
\text { frames) }\end{array}$ \\
\hline
\end{tabular}

\begin{tabular}{|c|c|c|c|}
\hline \multirow{2}{*}{$\begin{array}{l}\text { No./ } \\
\text { city/ } \\
\text { soil } \\
\text { type }\end{array}$} & \multirow{2}{*}{$\begin{array}{l}\text { Code } \\
\text { vers- } \\
\text { ion }\end{array}$} & \multicolumn{2}{|c|}{ Performance points } \\
\hline & & $\begin{array}{l}\text { Maximum } \\
\text { Level }\end{array}$ & Structure elements \\
\hline \multirow{2}{*}{$\begin{array}{r}7 / \\
\operatorname{Pdg} / \\
\mathrm{S}\end{array}$} & 2002 & LS & $\begin{array}{l}\text { Columns (floor } 1 \text {; edge and } \\
\text { middle frames) }\end{array}$ \\
\hline & 2012 & IO & $\begin{array}{l}\text { Columns (floor 1; edge and } \\
\text { middle frames) }\end{array}$ \\
\hline \multirow{2}{*}{$\begin{array}{r}8 / \\
\mathrm{Pdg} / \\
\mathrm{M}\end{array}$} & 2002 & $\mathrm{~B}$ & $\begin{array}{l}\text { Beams (floor 2-6); columns } \\
\text { (floor 1; edge and middle } \\
\text { frames) }\end{array}$ \\
\hline & 2012 & $\mathrm{IO}$ & $\begin{array}{l}\text { Columns (floor 1; edge } \& \\
\text { middle frames) }\end{array}$ \\
\hline \multirow{2}{*}{$\begin{array}{r}9 / \\
\mathrm{Pdg} / \\
\mathrm{H}\end{array}$} & \multirow[t]{2}{*}{2002} & B & $\begin{array}{l}\text { Beams (floor 2-6); columns } \\
\text { (floor 1) }\end{array}$ \\
\hline & & $\mathrm{B}$ & $\begin{array}{l}\text { Beams (floor 2-6); columns } \\
\text { (floor 1) }\end{array}$ \\
\hline \multirow{2}{*}{$\begin{array}{r}10 / \\
\mathrm{Bgkl} / \\
\mathrm{S}\end{array}$} & \multirow[t]{2}{*}{2002} & $\mathrm{C}$ & $\begin{array}{l}\text { Columns (floor 1, edge } \\
\text { frames) }\end{array}$ \\
\hline & & $\mathrm{IO}$ & $\begin{array}{l}\text { Columns (floor 1; edge \& } \\
\text { middle frames) }\end{array}$ \\
\hline \multirow[b]{2}{*}{$\begin{array}{r}11 / \\
\mathrm{Bgkl} / \\
\mathrm{M}\end{array}$} & \multirow[t]{2}{*}{2002} & IO & $\begin{array}{l}\text { Columns (floor } 1 \text {; edge } \& \\
\text { middle frames) }\end{array}$ \\
\hline & & $\mathrm{B}$ & $\begin{array}{l}\text { Beams (floor 2-6); columns } \\
\text { (floor 1; middle and edge edge } \\
\text { frames) }\end{array}$ \\
\hline \multirow{2}{*}{$\begin{array}{r}12 / \\
\mathrm{Bgkl} / \\
\mathrm{H}\end{array}$} & \multirow[t]{2}{*}{2002} & $\mathrm{~B}$ & $\begin{array}{l}\text { Beams (floor 2-6); columns } \\
\text { (floor 1; middle and edge edge } \\
\text { frames) }\end{array}$ \\
\hline & & $\mathrm{B}$ & $\begin{array}{l}\text { Beams (floor 2-5); columns } \\
\text { (floor 1; middle and edge edge } \\
\text { frames) }\end{array}$ \\
\hline
\end{tabular}

Notes:

Jkt: Jakarta; Bdg: Bandung; Pdg: Padang; Bgkl: Bengkulu; S: Soft soil; M: Medium soil; H: Hard soil.

Table 13. Structural performance level on ultimate condition

\begin{tabular}{|c|c|c|c|}
\hline \multirow[t]{2}{*}{ No. } & \multirow{2}{*}{$\begin{array}{l}\text { Code } \\
\text { vers- } \\
\text { ion }\end{array}$} & \multicolumn{2}{|c|}{ Ultimate condition } \\
\hline & & $\begin{array}{l}\text { Maximum } \\
\text { Level }\end{array}$ & Structure elements \\
\hline \multirow{2}{*}{$\begin{array}{r}1 / \\
\mathrm{Jkt} / \\
\mathrm{S}\end{array}$} & \multirow{2}{*}{$\begin{array}{r}2002 \\
2012 \\
\end{array}$} & LS & $\begin{array}{l}\text { Columns (floor 1, edge and } \\
\text { middle frames) }\end{array}$ \\
\hline & & LS & $\begin{array}{l}\text { Columns (floor } 1 \text {, edge and } \\
\text { middle frames) }\end{array}$ \\
\hline \multirow{2}{*}{$\begin{array}{r}2 / \\
\mathrm{Jkt} / \\
\mathrm{M}\end{array}$} & \multirow{2}{*}{$\begin{array}{l}2002 \\
2012\end{array}$} & LS & $\begin{array}{l}\text { Columns (floor } 1 \text {, edge and } \\
\text { middle frames) }\end{array}$ \\
\hline & & LS & $\begin{array}{l}\text { Columns (floor } 1 \text {, edge and } \\
\text { middle frames) }\end{array}$ \\
\hline \multirow{2}{*}{$\begin{array}{r}3 / \\
\mathrm{Jkt} / \\
\mathrm{H}\end{array}$} & \multirow[t]{2}{*}{2002} & LS & $\begin{array}{l}\text { Columns (floor 1, edge and } \\
\text { middle frames) }\end{array}$ \\
\hline & & LS & $\begin{array}{l}\text { Columns (floor } 1 \text {, edge and } \\
\text { middle frames) }\end{array}$ \\
\hline \multirow{2}{*}{$\begin{array}{r}4 / \\
\mathrm{Bdg} / \\
\mathrm{S}\end{array}$} & 2002 & $\mathrm{C}$ & $\begin{array}{l}\text { Columns (floor 1; edge } \\
\text { frames) }\end{array}$ \\
\hline & 2012 & $\mathrm{C}$ & $\begin{array}{l}\text { Columns (floor 1; edge } \\
\text { frames) }\end{array}$ \\
\hline \multirow{2}{*}{$\begin{array}{r}5 / \\
\text { Bdg/ } \\
\mathrm{M}\end{array}$} & 2002 & LS & $\begin{array}{l}\text { Columns (floor 1, edge and } \\
\text { middle frames) }\end{array}$ \\
\hline & 2012 & LS & $\begin{array}{l}\text { Columns (floor } 1 \text {, edge and } \\
\text { middle frames) }\end{array}$ \\
\hline \multirow{2}{*}{$\begin{array}{r}6 / \\
\text { Bdg/ } \\
\mathrm{H}\end{array}$} & 2002 & LS & $\begin{array}{l}\text { Columns (floor 1, edge and } \\
\text { middle frames) }\end{array}$ \\
\hline & 2012 & LS & $\begin{array}{l}\text { Columns (floor } 1 \text {, edge and } \\
\text { middle frames) }\end{array}$ \\
\hline
\end{tabular}




\begin{tabular}{|c|c|c|c|}
\hline \multirow[t]{2}{*}{ No. } & \multirow{2}{*}{$\begin{array}{l}\text { Code } \\
\text { vers- } \\
\text { ion }\end{array}$} & \multicolumn{2}{|c|}{ Ultimate condition } \\
\hline & & $\begin{array}{l}\text { Maximum } \\
\text { Level }\end{array}$ & Structure elements \\
\hline \multirow{2}{*}{$\begin{array}{r}7 / \\
\text { Pdg/ } \\
\mathrm{S}\end{array}$} & 2002 & C & $\begin{array}{l}\text { Columns (floor 1; edge } \\
\text { frames) }\end{array}$ \\
\hline & 2012 & C & $\begin{array}{l}\text { Columns (floor 1; edge } \\
\text { frames) }\end{array}$ \\
\hline \multirow{2}{*}{$\begin{array}{r}8 / \\
\mathrm{Pdg} / \\
\mathrm{M}\end{array}$} & 2002 & LS & $\begin{array}{l}\text { Columns (floor 1, edge and } \\
\text { middle frames) }\end{array}$ \\
\hline & 2012 & LS & $\begin{array}{l}\text { Columns (floor } 1 \text {, edge and } \\
\text { middle frames) }\end{array}$ \\
\hline \multirow{2}{*}{$\begin{array}{r}9 / \\
\text { Pdg/ } \\
\mathrm{H}\end{array}$} & 2002 & LS & $\begin{array}{l}\text { Columns (floor 1, edge and } \\
\text { middle frames) }\end{array}$ \\
\hline & 2012 & LS & $\begin{array}{l}\text { Columns (floor 1, edge and } \\
\text { middle frames) }\end{array}$ \\
\hline \multirow{2}{*}{$\begin{array}{r}10 / \\
\text { Bgk1/ } \\
\mathrm{S}\end{array}$} & 2002 & $\mathrm{C}$ & $\begin{array}{l}\text { Columns (floor 1; edge } \\
\text { frames) }\end{array}$ \\
\hline & 2012 & $\mathrm{C}$ & $\begin{array}{l}\text { Columns (floor 1; edge } \\
\text { frames) }\end{array}$ \\
\hline \multirow{2}{*}{$\begin{array}{r}11 / \\
\text { Bgkl/ } \\
\mathrm{M}\end{array}$} & 2002 & $\mathrm{C}$ & $\begin{array}{l}\text { Columns (floor 1; edge } \\
\text { frames) }\end{array}$ \\
\hline & 2012 & $\mathrm{C}$ & $\begin{array}{l}\text { Columns (floor 1; edge } \\
\text { frames) }\end{array}$ \\
\hline \multirow{2}{*}{$\begin{array}{r}12 / \\
\text { Bgk1/ } \\
\mathrm{H}\end{array}$} & 2002 & LS & $\begin{array}{l}\text { Columns (floor 1, edge and } \\
\text { middle frames) }\end{array}$ \\
\hline & 2012 & LS & $\begin{array}{l}\text { Columns (floor 1, edge and } \\
\text { middle frames) }\end{array}$ \\
\hline
\end{tabular}

The structural levels of performance points became more severe from yield (B) to Immediate Occupancy (IO) and yield (B) to yield (B) with more damaged plastic hinges, respectively, on the structural models in Padang city of medium and hard soil. This was caused by the higher of maximum spectral response acceleration parameters $\left(C_{v}\right.$ or $\left.S_{a}\right)$ in the current earthquake code [3] than the previous one [2], where the values changed from 0.83 to 0.931 on medium soil and 0.70 to 0.931 on hard soil. The higher spectral response acceleration parameters caused a more severe earthquake load to the structural models and lowered the structural performance.

The opposite behaviour was showed by the structural models in Padang on soft soil and Bengkulu on soft and medium soil, where the structural performance levels of performance point were better from Life Safety (LS) to IO, Collapse (C) to IO, and IO to yield (B). This was because the maximum spectral response acceleration parameters in the current code [3] was less than in the previous code [2] for Padang on soft soil and Bengkulu cities on soft and medium soil, i.e. 0.838 [3] and 0.900 [2]; 0.678 [3] and 0.950 [2], 0.790 [3] and 0.950 [2], respectively.

Other structural models showed the same performance levels according to the previous [2] and current codes [3], such as in Jakarta and Bandung cities on soft soil, in accordance with the IO levels, as well as the medium and hard soils in (B) levels. In the ultimate condition, the structural performance levels of all models were the same which were analysed by the previous [2] and current codes [3]. All structural performance levels on performance point and ultimate condition are presented in Tables 12 and 13, respectively.

\section{Conclusions}

From the modelling results, the following conclusions were derived:

1. The pushover analysis provides structural models performance in resisting earthquake loads by showing performance levels.

2. The current Indonesian earthquake code (SNI 17262012) provides different response spectrum curves compared to the previous (SNI 1726-2002). It implicates more or less severe earthquake loads depending on the areas. The pushover analysis on structural models showed that the different structural performance levels on performance points depended on the various maximum spectral response acceleration values in the codes.

3. The pushover analysis of structural models in Padang city on the medium and hard soil showed that the structural levels of performance points were more severe from yield (B) to Immediate Occupancy (IO) and yield (B) to yield (B) with more damaged plastic hinges, respectively, due to higher spectral response acceleration parameters in the current code. This condition needs to be considered by engineers in designing proper new structures or evaluating existing structures to resist earthquake loads.

4. The pushover analysis of structural models in Padang on soft soil and Bengkulu cities on soft and medium soil showed that the structural levels of performance points improved from Life Safety (LS) to IO, Collapse (C) to IO, and IO to yield (B) due to the decreased maximum spectral response acceleration parameters in the current code.

5. The pushover analysis of structural models in Jakarta and Bandung on soft, medium, and hard soil, and Bengkulu on hard soil showed the same performance levels according to the SNI 1726-2002 and SNI 17262012 codes.

\section{Recommendations}

These following recommendations are necessary for further studies:

1. The details of structural reinforcement constructed based on SNI 1726-2002 in some areas that resisted more severe earthquake loads due to higher maximum earthquake response factor in SNI 1726-2012 need to be further analyzed.

2. Other buildings were constructed in various shapes, even in asymmetric and rounded shapes. They had various hinge properties and provided different structural performance levels.

3. The structural design process needs to analyze other types of building, such as open frames strengthened by shear walls to provide better performance in resisting earthquake loads. 


\section{References}

1. California Seismic Safety Commission, Applied Technology Council 40 Volume 1: Seismic Evaluation and Retrofit of Concrete Buildings, (1996).

2. National Standardization Board, SNI 1726-2002 Procedure for Earthquake Resistant Design of Building Structures (in Indonesian; 2002).

3. National Standardization Board, SNI 1726-2012 Procedure for Earthquake Resistant Design of Building and Non-Building Structures (in Indonesian; 2012).

4. J.R. Qian, W.J. Zhang, and X.D. Ji, The 14th World Conference on Earthquake Engineering, Beijing (2008).

5. Computers \& Structures, Inc., SAP2000: Integrated Software for Structural Analysis and Design v.14.1.0, Berkley, CA, USA.
6. National Standardization Board, SNI 03-2847-2013 Code of Structural Concrete Requirements of Building Structures, (in Indonesian; 2013).

7. R.A. Hakim, M.S. Alama, S.A. Ashour, Arab Journal Science Engineering 39:7691-7699 (2014).

8. E.C. Bentz and M.P. Collins, Response 2000 v. 1.0.5, University of Toronto.

9. T. Paulay and M.J.N. Priestly, Seismic Design of Reinforced Concrete and Masonry Buildings, John Willey \& Sons (1992).

10. R.A. Hakim, Seismic Assessment of RC Building Using Pushover Analysis, International Journal of Engineering and Technology Development 1 (3) ISSN 2337-3180 (2013).

11. Computers \& Structures, Inc., Bridge: Integrated 3-D Bridge Analysis, Design, and Rating, CA (2017)

12. http://puskim.pu.go.id/Aplikasi/desain_spektra_indo nesia_2011/. Accessed on 17th May 2019. 